Journal of English Language Teaching and Applied Linguistics

ISSN: 2707-756X

DOI: $10.32996 /$ jeltal

Journal Homepage: www.al-kindipublisher.com/index.php/jeltal

JELTAL

\title{
A Contrastive Study of Teaching and Learning strategies of the Adverb of Range "都" and "đều" in Chinese and Vietnamese
}

\author{
Hong Nguyet Binh 8 (D) \\ Ho Chi Minh City University of Food Industry, Ho Chi Minh City, Vietnam \\ $\triangle$ Corresponding Author: Hong Nguyet Binh, E-mail: binhhn@hufi.edu.vn
}

\section{ARTICLE INFORMATION ABSTRACT}

Received: May 08, 2021

Accepted: June 14, 2021

Volume: 3

Issue: 6

DOI: 10.32996/jeltal.2021.3.6.16

\section{KEYWORDS}

Adverb of range "都",

"đều", "cũng",

analyzing errors
Adverbs play a vital role in both Chinese and Vietnamese. All adverbs belong to expletive words. That means they do not have any real meanings. They only express their value through grammatical aspects. This study analyses and contrasts the adverb "đều" in Chinese and Vietnamese based on the syntactic, semantic, pragmatic context. Reviewing and contrasting methods is used to carry out this study. Thus, the similarities and differences when using the adverb of range "都" and "đều" between the two languages will be pointed out. Some recommendations are given not only for students but also for teachers. The study is expected to be useful to help teachers in their teaching process and students in their learning one.

\section{Introduction}

In the process of interacting and teaching students at Ho Chi Minh City University of Food Industry (HUFI), the author realized that most of them often confuse the Vietnamese words "đều", "cũng" with the Chinese word "都" (du), especially with students who are new to Chinese. Learners do not know when the adverbs "đều" and "cũng" are replaced by the adverb of range "都" and vice versa when they are translated into Chinese. Sometimes, the words "đều" and "cũng"' appear in the same sentence at the same time, but when translating into Chinese, students do not know how to translate to fit the context, or what words are often combined with the word "都" and how they are structured and meaningful, etc., due to not knowing their grammatical features, there have been a number of situations that not to know whether to laugh or cry not only for learners but also for teachers as the grammatical types of Chinese and Vietnamese are both SVO. This structure has more similarities but fewer differences, and some are even completely opposite in the two languages. In the book "Vietnamese grammar", the adverb "đều" does not have a unified/definition name. Some scholars classify it as a continuous or consistent adverb (Quynh, 2007) and some classify it as adverbs in the group of comparison and process (Ban D. Q., 2013). But in general, the scholars temporarily agree to classify it as "the adverbs of range" in order to facilitate the comparison.

Therefore, this research paper is based on the results of previous works and the linguistic and semantic backgrounds. It highlights the characteristics of the words "đều" and "都" in the two languages in order to avoid unnecessary errors. At the same time, the author combines with research reviewing and contrasting methods to propose a number of methods to help second language learners and teachers effectively in the process of Chinese language teaching and learning through the comparison and analysis of common mistakes of learners.

The contrast of the adverb of range "都" is very meaningful as the grammatical types of Chinese and Vietnamese are both SVO. This structure has more similarities but fewer differences, and some are even completely opposite in the two languages. Therefore, when conducting the contrast of the adverb of range "都" in the two languages, this study is based on the results of previous works. The semantic and syntactic contexts are considered to contrast this adverb aiming at pointing out learners' basic errors to facilitate their learning process.

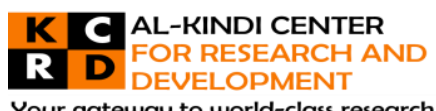

Your gateway to world-class research

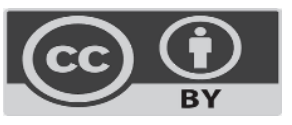

Published by Al-Kindi Center for Research and Development, United Kingdom. Copyright (c) the author(s). This open access article is distributed under a Creative Commons Attribution (CC-BY) 4.0 license 
In the book "Vietnamese grammar", the adverb "đều" does not have a unified name. Some scholars classify it as a continuous or consistent adverb (Quynh, 2007) and some classify it as adverbs in the group of comparison and process (Ban D. Q., 2013). But in general, the scholars temporarily agree to classify it as "the adverbs of range" in order to facilitate the comparison.

\section{Literature Review}

\subsection{Definition of the adverb "đều" in Chinese}

According to the reprinted version of "实用现代汉语语法" (tentatively translated as "Practical grammar of modern Chinese"), the adverb "都" is defined as "Expressing the range which is used to summarize the preceding verbs or adjectives." (刘月华，潘文娱， \& 故华, 2013). But Zhang Yisheng gave a detailed analysis of the adverb "都" is "a general adverb of range" in the "现代汉语副词 探索" (tentatively translated as "Modern Chinese Adverbs") (张谊生著, 2004). For example，

(1) 今天 大家 [都]去参加学校的课外活动。

Hôm nay, mọi người [đều] đi tham gia hoạt động ngoại khóa của trường.

(2) 冰箱里[都]是糖果。

Trong tủ lạnh [đều] là kẹo.

(3) 李伯伯每天[都]起得很早。

Bác Lý mỗi ngày [đều] thức dạy sớm.

If the people or things which are mentioned above are all plurals, "都" "could have 3 types of general expression" (刘月华，潘文 娱，\&故华, 2013), for example:

(4) 这几部电视剧我们[都]看过了。

Những bộ phim truyền hình này chúng tôi đều đã xem qua.

In example (4), there are 3 types of general possibilities of "都": the first is "这几部电视剧", the second is "我们", the third is of the two types mentioned above. If the learners want to determine what type it is, they have to consider the context of sentences to judge or the content emphasized by the speaker to infer. The adverb "都" ("đều") usually "goes after the words it contains" (刘月华，潘文娱，\&故华，2013).

As mentioned in the book "现代汉语" (tentatively translated as "Modern Chinese") by 齐沪杨, the adverbs have 3 syntactic functions. One is that it cannot be used as a predicate, but only used as an adverbial; the other is that adverbs have dependent properties, so most of them can not be used independently; the third is, some are related properties, some can be used independently, some can be used together, some can be used by combining the first and second function, and some can be used in conjunction with conjunctions (齐泸杨编, 2012). Based on the above explanation, it can be inferred that "the only syntactic function of "都" is an adverbial" (房玉清著, 2008) which modifies or bounds its following verbs, adjectives and it can not be used as an independent sentence because it only has meaning in terms of grammatical meaning and grammatical function.

\subsection{Definition of the adverb "đều" in Vietnamese}

In Vietnamese grammar, there is no specific explanations about what classification of adverb the word "đều" belongs to. But according to "Vietnamese grammar" of Diep Quang Ban and Hoang Van Thung, the adverb "đều" "expresses comparison of things of same properties or things in a certain space and time". For example:

(5) Những thứ ở đây [đều]bị động đất hủy hoại hết rồi.

(6) 地震把这里的东西[都]毁坏了。

(7) Mọi người [đều] đã đi hết rồi, sao bạn không đi.

(8) 大家都去了, 你为什么不去呢。

(9) Họ [đều] ăn được, bạn cũng có thể ăn được.

(10) 他们都能吃, 你也能吃。

From the example (5), (7), (9), it can be seen that "đều" all means the consensus of things or things happen in the same space and time, and most of the preceding subjects are plural 
From the perspective of the meaning of the adverb "đều", the author points out its grammatical function. This adverb has only grammatical meaning but has no meaning of words as well as real meaning. It has grammatical complexity and appearing only when the plural is mentioned before it. Based on this feature, it can be assumed that the syntactic function of "đều" seems to be the same as the adverb of range "都" in Chinese, but "đều" cannot be used independently in sentences, and both are modifiers for verbs and adjectives. For example:

(11) Mọi người [đều] đi tham gia lễ hội, trừ anh ấy không đi.

(12) 大家 [都] 去参加晚会, 除了他没去。

(13) Mọi người [đều] phải đi.

(14) 每个人 [都] 要去。

(15) Mình không hiểu tại sao mọi người [đều] phản đối.

(16) 我不明白, 为什么大家[都] 反对。

(17) Hôm nay lớp chúng ta [đều] đi tham gia hoạt động ngoài giời.

(18) 今天咱们班[都] 去参加课外活动。

\section{Methodology}

\subsection{Reviewing Method}

It is used as the primary method in this study. The author specifies the study's title then the materials are looked for and evaluated whether they are related to the research. The suitable materials and the results of previous works will be used to compare.

\subsection{Contrasting Method}

This method is used to analyze the errors of learners due to interlanguage and give some learning methods for learners. The author implemented as follows.

- $\quad$ Reading the found materials and taking notes of the similarities and differences related to the title

- Taking notes of the teaching and learning process of the Chinese - Vietnamese adverb of range "都" and "đều"

- Pointing out the similarities and differences of the Chinese - Vietnamese adverb of range "都" based on semantic, pragmatic, and grammatical perspectives

\section{Results and Discussion}

\subsection{The Chinese - Vietnamese contrast}

\subsubsection{The similarities}

Most of the subjects of the Chinese - Vietnamese adverb of range "都", which expresses the meaning of "all", are plural. When " 各"，“所有"，“一切"，“那些"，"随时"，“到处"，"任何" ("Every", "all", "everything", "those", "anytime", "anywhere", "any") appear in the sentence, the predicate often has "都". Moreover, "都” can be combined with "不管", “无论", "不论" ("no matter") to form a structure (刘月华, 潘文娱，\&故华，2013). For example:

(19) 每个人 [ 都] 能去。(Mọi người [đều] có thể đi.)

(20) 全部的事 , 我 [都] 交给他了。(Mọi thứ tới [đ̛̂̀u] giao cho cậu ấy rồi.)

In addition, the Chinese - Vietnamese adverb of range "都" can be combined with interrogative pronouns, adverbs of time, nouns, and repetitious quantifiers. On the other hand, this adverb can be used together with "连", "甚至" ("even") and the numeral "一" ("one") (刘月华，潘文娱，\& 故华，2013)，but when it is used with the adverbs of time (已经，快要，会等的词语 ("already", "about to be", "will")) and negative words (不和没 ("not")), the adverb "都" must be placed in front of these words. For example,

(21) 我等了很久 , 他们 [都] 没来。(Tới đợi rất lâu rồi, họ [đều] chưa đến.)

(22) 人人 [都]说他是个好人。(Mọi người [đều] nói anh ta là người tốt.)

(23) 今天大家 [都] 不用去上课。(Hôm nay chúng ta [đều] không có tiết học.) 


\subsubsection{The differences}

The adverbs of range "都" and "đều" in Chinese and Vietnamese are analyzed based on semantic and grammatical perspectives because the adverb "都" in Chinese is equivalent to the two words "đều" and "cũng" in Vietnamese. So, it can be listed in the following table:

\begin{tabular}{|c|c|c|}
\hline \multirow{3}{*}{$\begin{array}{l}\text { The adverb of } \\
\text { range " 都" in } \\
\text { Chinese }\end{array}$} & \multicolumn{2}{|c|}{ The adverb of range “都” in Vietnamese } \\
\hline & & $\begin{array}{l}\text { Using the word "đều" to describe things with the same properties or in a certain time or } \\
\text { space }\end{array}$ \\
\hline & Definition & $\begin{array}{l}\text { Using "cũng" to denote a process, a continuity property, and repeating the same properties } \\
\text { of things (Ban D. Q., 2013). (The word "cũng" is also equivalent to "也" ("also") in Chinese, but } \\
\text { it is not a duplicate adverb in this study.) }\end{array}$ \\
\hline
\end{tabular}

(i) Figure 1

\subsubsection{From the perspective of semantic}

Throughout the contrast of the adverbs of range in Chinese and Vietnamese (see Figure 1), it can be noticed that the word "都" in Chinese equivalent to "đều" and "cũng" in Vietnamese. For example:

(24) 见了面, 他一句话 [都] 不说。

(25) Gặp mặt rồi, điều gì anh ấy [cũng] không nói.

(26) 连他 [都] 不知道, 何况是你呢。

(27) Kể cả anh ấy [cũng] không biết, huống chi là mày.

Both the example (25) and (27) mention the process of things, so it is appropriate to use "cũng", instead of "đều". Normally, the word "cũng" is used in a specific situation in Vietnamese (see Figure 1) for the purpose of emphasis, but "đều" does not have such meaning. Besides, the word "cũng" is always used in combination with "whatever" (无论，不管，不论), but the word "đều" can not combine with these three words.

(28) 无论在什么情况下, 她 [都] 尽力而为。

(29) Trong bất kỳ tình huống nào, cố ấy [cũng] làm hết sức mình.

(30) Trong bất kỳ tình huống nào, cố ấy [đều] làm hết sức mình.

Because Vietnamese students do not know this feature when they are studying Chinese, so they usually confuse or interchange when using "也" and "都".

(31) 不管你选哪个, 它 [都] 是一样的。

(32) Cho dù bạn chọn cái nào, thì nó [cũng] như nhau.

(33) Cho dù bạn chọn cái nào, thì nó [cũng đều] như nhau.

(34) 每道菜 [都] 好吃。

(35) Món ăn nào [cũng] ngon.

(36) Món ăn nào [đều cũng] ngon.

Since "đều" and "cũng" are synonyms then they can not only appear in the same sentence, but the other adverbs such as "đã" (已经) (already) are also possible added (Ban D. Q., 2009). For example,

(37) [Đều cũng đã] ba mươi tuổi rồi, vẫn không biết suy nghĩ.

(38) [已经][都] 三十岁了, 还不懂得想。

\subsubsection{From the perspective of pragmatic}

The adverb of range "都" in Chinese itself, sometimes, contains the meaning of "已经" ("already"). Generally, there is "了" at the end of a sentence, but the word "đều" in Vietnamese does not have this characteristic. However, if the speaker wants to use "đã" ("already"), it must be borrowed from the Vietnamese language, for example:

(39) [都] 那么晚了, 你还不回来。

(40) [Đã] khuya như vậy, con vẫn chưa chịu về. 
(41) 他们 [都] 等了很久。

(42) Họ [đã] đợi rất lâu rồi.

(43) 多少年了 , 咱们 [都] 没见面。

(44) Bao năm rồi, chúng ta [đã] không gặp nhau.

"都" in the example (39), (41), (43) means the past tense with an emphasis on the tone, while "都" in Vietnamese does not mean this. If the example (40), (42), (44) are changed into "đều" to emphasize the tone, their meanings changed. For example, the example (40) is rewritten as "[Đều] khuya như vậy, con vẫn chưa chịu về.". The meaning is a bit different. The speaker of the example (40) uses "đã" to emphasize the passage of time, but "đều" does not have this meaning.

As presented above, "đều" and "đã" can be used in combination in the example (40), (42), and (44) ("đều cũng đã", sometimes, can be used at the same time.), however, the meaning remains the same. For example,

(45) Họ [đều cũng đã] đợi rất lâu rồi. ( 他们都等了很久。 )

They [all have also waited] a very long time.

In other words, Vietnamese students do not know the Chinese adverb of range "都" has this feature (meaning "đã"), so they often have difficulty in learning. Sometimes, they often mistakenly think when using "都" becomes "也" (adverb of time).

In short, Chinese-Vietnamese adverbs of the range have similarities but also differences, though it is more flexible to use adverbs of range "都" in Chinese, so Vietnamese students often rely on their perception of the language and context of sentences to guess if a sentence is right or wrong.

\subsection{The errors analysis}

\subsubsection{The gap of errors}

The gap of errors is the lack of a necessary element in a sentence that leads to a wrong sentence. For example:

(46) *那个时候, 突然间轰了一声, 大家 [ ] 不回头看。

Vào lúc đó, tiếng nổ vang lên đột ngột, mọi người [ ] không quay đầu nhìn.

(47) *妈妈告诉女儿, 去哪儿个地方 [ ] 不能一个人去。

Mẹ bảo với con gái, đi đâu [] không thể đi một mình.

The example (46), (47) lack the adverb of range "都". The correct sentence of example (46) is "那个时候, 突然间轰了一声, 大家 [ 都] 不回头看。 and example (47) is “妈妈告诉女儿, 去哪儿个地方 [ 都] 不能一个人去。” Vietnamese students rarely make errors in Chinese in the two sentences above because they often rely on their feelings to judge.

\subsubsection{The errors}

Adding errors is indicating words or phrases that are used inappropriately in sentences. For example,

(48) *我的生活 [ 都] 像枯井一样, 平淡乏味。

Cuộc sống của tôi [đều] giống như giếng khô, đơn sơ và tẻ nhạt.

In the example (48), "都" modifies "我的生活", but "我的生活" does not emphasize the general meaning, so it could be corrected as"我的生活像枯井一样, 平淡乏味。

\subsubsection{The out-of-sequence errors}

Incorrect order is also called incorrect position, which indicates the inappropriateness in the position of a sentence element or word. Because the adverb of range "都" in Chinese - Vietnamese are different, so the mistakes in the learning process can not be avoided. For example:

(49)*他把老师 [都] 对她所说的话忘掉了。

Hắn đã quên những gì giáo viên [đều dã] nói với hắn.

As mentioned above, "都" is used to summarize the preceding things and it should generally be placed after the words it includes. Therefore, in example (49), it is corrected as “他把老师对她所说的话[都] 忘掉了。 


\subsubsection{The errors of replacement}

The error of replacement is the error of misuse. Because Vietnamese students have not yet mastered the usage of the Vietnamese adverb "đều" (see Table 1), therefore, it is undoubtedly changed to "也". Vietnamese students are easy to make mistakes when using the adverb "đều", especially for beginners. For example:

(50) *无论你说什么我 [也] 不会听的。

Bất kể anh nói gì tôi [cũng/đều] không tin.

(51) *不管怎么样, 我 [也] 要去看看。

Dù sao đi nũa, tôi [cũng] phải đi xem xem.

Because "都" in Vietnamese also means "也", so Vietnamese students often confuse these two words. They use the word "也" where it is necessary to use "都" or vice versa. In example (50), (51), "也" should be changed into "都".

\subsection{The causes of the errors}

\subsubsection{The negative transfer of mother tongue}

The main reason for the negative transfer of the mother tongue is that the learners are not familiar with the rules of the target language, so they can only rely on the knowledge of the mother tongue to guess, or they have not mastered the knowledge of the mother tongue, as a result, the errors are made.

Therefore, sometimes when Vietnamese students make sentences, it is inevitable that sentences like this often appear: "你看这里 的风景, 到处[也]是树". It can be seen that the negative transfer of the mother tongue is one of the main reasons for Vietnamese students.

\subsubsection{The negative transfer of target language}

The main reason for the negative transfer of the target language is an excessive generalization. When learners do not fully grasp or limit the knowledge of the target language, they often use analogy methods to apply to the target language, which results in errors.

In summary, when Vietnamese students use the Chinese adverb of range "都" in the process of learning Chinese, the abovementioned errors often occur. Therefore, in order to be able to learn the target language well, Vietnamese students should have good learning strategies to avoid them.

\section{Conclusion and Suggestions}

\section{1 Conclusion}

Based on the research results of the predecessors of Chinese - Vietnamese, this study uses the method of comparing the two languages to refer to the adverb "都", and then contrast the semantic and pragmatics perspective of "đều" through the adverb of range "都" in Chinese. Finally, through comparison, the similarities and differences, or even opposites of the adverbs of range "都" and "đều" are all pointed out. From the definition, this study briefly describes the definitions of "都" and "đều" and points out their grammatical functions; from a semantic perspective, the two languages are basically similar, but from a pragmatic perspective, the Chinese "都" is equivalent to the Vietnamese "đều" and "cũng" or even "đã". Therefore, it is inevitable that errors will be made in the application, which will cause errors.

The characteristics of a thing can only be brought out by comparing it with other things. This study is not an exception. Indeed, through comparative analysis, Vietnamese students' learning the adverb of range "都" often has the above four kinds of errors. The main reason is caused by the negative transfer of the mother tongue.

\subsection{Suggestions}

Some teaching and learning strategies of the adverb of range "都" are briefly proposed in this study. Therefore, comparing the Chinese - Vietnamese the adverb of range is beneficial to the acquisition. 


\section{1 Learning strategy}

Because the Chinese adverb of range "都" is sometimes equivalent to the Vietnamese adverbs "đều" and "cũng", and the meaning of Vietnamese word "cũng" is sometimes equivalent to the Chinese adverb "也". Therefore, Vietnamese learners are very easy to confuse as in the examples (26) and (27) because the learners do not know in what contexts it is appropriate to use "đều" or "cũng". This is a difficult point for Vietnamese learners. In addition, "都" is often used in conjunction with "了" which means "đã" (already) as the example (39). When doing Chinese - Vietnamese translation or vice versa, the learners do not realize this problem and often use "đều" in sentences that contain the meaning "đã" (already), but "đều" does not have this meaning in Vietnamese, so the Vietnamese adverb of time "đã" is often used in translation. However, there are some situations that "đều", "cũng" and "đã" can appear in the same sentence at the same time, but it only uses the format "都... 了" when it is translated into Chinese as in the example (44). This is also a difficult point for learners. Because of this, learners are required to have the ability of answer, deduce, reality, memorization, and observation when learning a second language. They should have methods and measures to overcome difficulties when encountering grammatical difficulties, and they should have an active learning attitude and a motivation to learn.

\subsubsection{Teaching strategy}

When teaching grammar, teachers must understand the semantics, pragmatics, and sentence patterns of this grammar well. In particular, it is necessary to grasp the three meanings of "都": the general scope, the tone of emphasis, and the explanation of reasons which usually has the tone of complaint (北京大学中文系 1955 和 1957 级语言班遍，1996). Teachers should have classroom practice precisely based on the practical principles which are from simple to intensive ones, the principles of communication, and give learners a lot of opportunities for practicing; focus on exercises, and highlight the key points and difficulties of the "都" grammar in Chinese - Vietnamese. The teacher's explanations should be small and precise, and the necessary explanations should be provided to let the learners understand the grammar rules. According to the degree of learner's acquisition, it is divided into different stages, from the shallower to the deeper, and gradually improves the ways of using the "都". In addition, teachers are required to be enlightening the learners' interest during the teaching process, which will help the learners feel more interested in learning grammar.

If the learners do not master the target language, it is difficult to understand and express correctly. Besides, when learners make mistakes that are caused by the negative expression in their mother tongue. As long as teachers introduce corresponding rules and make clear explanations in the teaching process, they can help learners avoid mistakes and improve their learning efficiency.

In brief, grammar is the main content of language teaching, and mastering grammatical rules are the basis of teaching a second language because it is conducive to understanding and using language. Therefore, in the teaching process, teachers not only embody the normalization, stability, and practicality of this grammar, they can also adopt inductive or deductive methods, or combine those two teaching methods, and use different skills flexibly to elicit grammatical points. Teachers should be studentcentered to teach and practice from language to speech. Moreover, teachers should also pay attention to their own and their students' frame of mind.

Due to the author's limited knowledge and insufficient level, errors or shortcomings will inevitably occur when comparing. Therefore, the comments are expected to make this study better.

Funding: "This research received no external funding."

Acknowledgments: A sincere thank you is sent to all the colleagues of the Faculty of Foreign Languages at the Ho Chi Minh City University of Food Industry for their support from the beginning of the study. All of the suggestions for the study are highly appreciated. The author, however, bears full responbility for the paper.

Conflicts of Interest: "The authors declare no conflict of interest. "

\section{References}

[1] Ban, D. Q. (2009). Ngữ pháp Tiếng Việt (Vol. 2). Hà Nội: NXB Giáo dục.

[2] Ban, D. Q. (2013). Ngũ pháp Tiếng Việt (ed. 14th, Vol. 1). Hà Nội: NXB Giáo dục.

[3] Quynh, N. H. (2007). Ngữ pháp Tiếng Việt. Hà Nội: NXB Từ điển Bách Khoa Hà Nội.

[4] 刘月华, 潘文娱, \& 故华. (2013). 实用现代汉语语法. 北京: 商务印书馆.

[5] 北京大学中文系 1955 和 1957 级语言班遍. (1996). 现代汉语虚词例释. 北京: 商务印书馆.

[6] 张谊生著. (2004). 现代汉语副词探索. 上海: 学林出版社.

[7] 房玉清著. (2008). 使用汉语语法 (ed. 2nd). 北京: 北京语言大学.

[8] 齐泸杨编. (2012). 现代汉语. 北京: 商务印书馆. 